\title{
GAMBARAN TINGKAT DEPRESI PADA WANITA PEKERJA SEKS DI KALANGAN REMAJA DI KOTA MANADO
}

\author{
Serly Wardoyo \\ Theresia M. D. Kaunang \\ Herdy Munayang
}

\author{
${ }^{1}$ Kandidat Skripsi Fakultas Kedokteran Universitas Sam Ratulangi Manado \\ ${ }^{2}$ Bagian Psikiatri Fakultas Kedokteran Universitas Sam Ratulangi Manado \\ Email: serly.wardoyo@gmail.com
}

\begin{abstract}
Depression is a mental disorder that is predicted by the World Health Organization which will be ranked first in the burden of disease on a global scale in 2030. Emotional maturity of the teens which is still unstable, highly susceptible to depression. Especially for those who work as female sex workers and often receive negative pressure when they work. Method: This research is a descriptive study with cross-sectional design. Depression among 30 adolescent FSWs will be assessed using the Beck Depression Inventory II questionnaire. Results: Results showed that 10.0\% FSWs are normal, 30.0\% FSWs have mild depression, 36.7\% FSWs have moderate depression and 23.3\% FSWs have severely depression.
\end{abstract}

Keywords: Depression, Female Sex Worker, adolescent, Beck Depression Inventory.

\begin{abstract}
Abstrak: Depresi merupakan gangguan mental yang diprediksikan oleh World Health Organization kelak menduduki peringkat pertama beban penyakit dalam skala global pada tahun 2030. Usia remaja yang kematangan emosionalnya masih labil, sangat rentan mengalami depresi. Apalagi bagi remaja yang berprofesi sebagai Wanita Pekerja Seks yang kerap mendapat berbagai tekanan negatifdalam pekerjaannya. Metode: Penelitian ini bersifat deskriptif dengan desain penelitian cross-sectional. Tingkatan depresi pada 30 remaja WPS akan dinilai dengan menggunakan kuesioner Beck Depression Inventory II. Hasil: Didapatkan sebanyak 10.0\% WPS normal, 30.0\% WPS mengalami depresi ringan, 36.7\% WPS mengalami depresi sedang dan 23.3\% WPS mengalami depresi berat.
\end{abstract}

Kata Kunci: Depresi, Wanita Pekerja Seks, remaja, Beck Depression Inventory.

Kaplan mendefinisikan depresi sebagai suatu keadaan dimana terjadi gangguan fungsi manusia yang berkaitan dengan alam perasaan yang sedih dan gejala penyertanya, termasuk perubahan pada pola tidur dan nafsu makan, psikomotor, konsentrasi, anhedonia, kelelahan, rasa putus asa dan tidak berdaya, serta bunuh diri. ${ }^{1}$ WHOmemprediksikan, dalam dua dekade mendatang diperkirakan lebih dari 300 juta penduduk dunia akan mengalami gangguan depresi. Angka ini juga diprediksikan akanterus meningkat danpada tahun 2020 akan menjadi penyebab kedua terbanyak kecacatan setelah penyakit kardiovaskuler. ${ }^{2,3}$

Profesi sebagai seorang Wanita Pekerja Seks (WPS) atau yang lebih kita kenal dengan istilah wanita Pekerja Seks Komersial (PSK) adalah suatu golongan pekerjaan yang rentan mengalami gangguan depresi. ${ }^{4}$ Menurut sebuah studi di daerah Nigeria dan New South Wales, wanita yang berprofesi sebagai WPS terbukti memiliki risiko yang lebih tinggi mendapatkan tindakan kekeras-an (fisik, mental danseksual) ataupun ter-jerat dalam kasus candu narkoba dan obat terlarang, serta 
risiko tinggi terjangkit pe-nyakit menular akibat hubungan seksual. ${ }^{4,5}$

Beberapa studi juga menyimpulkan, ada beberapa alasan yang menjadikan profesi WPS sebagai suatu golongan pekerjaan yang rentan mengalami gangguan depresi. ${ }^{5,6}$ Salah satu alasan berhubungan dengan wilayah dimana WPS tersebut bekerja. Di Negara seperti Indonesia, khususnya di wilayah kota Manado, dimana profesi WPS adalah ilegal, tentunya para WPS sering mendapat stigma dan perlakuan negatif dari masyarakat sekitar. Tak jarang hal-hal tersebut dapat memicu suatu gangguan mental seperti gangguan depresi di kalangan WPS. ${ }^{7}$

Kesimpulan yang serupa juga didapatkan berdasarkansuatu riset di China, yakni ditemukannya prevalensi gangguan depresi sebesar $82.4 \%$ di antara kalangan WPS China. Meskipun tidak ditemukan data nasional di China yang bisa digunakan sebagai perbandingan, tetapi studi lain di China juga mendapatkan hubungan yang bermakna antara depresi dan WPS, yakni sebanyak30\% WPS di Chinaternyata mengalami gangguan depresi, 8\% di antaranya memiliki pikiran untuk bunuh diri, dan $9 \%$ melakukan aksi bunuh diri. ${ }^{8}$

Wanita yang berprofesi sebagai WPS tidak hanya berasal dari kalangan dewasa saja. Di era sekarang ini, wanita yang masih tergolong usia remajajustru mendominasi dunia prostitusi di pelbagai kota besar maupun kecil.Data hasil pemetaan Komisi Penanggulangan AIDS (KPA) di wilayah Manado juga menjangkau sekiranya ada 498 orang WPS yang tersebar di 6 kecamatan, yaitu Sario, Malalayang, Wenang, Wanea, Tikala dan Mapanget dan 42\% atau 214 di antaranya berasal dari kalangan remaja. ${ }^{9}$

Ketika seorang WPS remaja menjalani profesinya dengan rasa terpaksa atau adanya keinginan yang saling bertentangan, dimana seorang WPS dengan pelbagai alasannya memilih jadi WPS, dan pelbagai dampak negatif yang ia dapatkan setelah menjadi seorang WPS, dapat menimbulkan suatu konflik batin tersendiri. Konflik batin tersebut menurut Freud, dapat menimbulkan suatugangguan mental seperti depresi apalagi di usia remaja yang masih dalam tahap pematangan emosional. ${ }^{10}$

Prevalensi penderita depresi pada usia remaja memang menunjukkan peningkatan yang sangat tinggi dibandingkan dengan usia kanak-kanak dan usia dewasa. Penelitian yang dilakukan oleh Radloff dan Rutter pada remaja-remaja di antara ras-ras yang berbeda menemukan bahwa gejala depresi meningkat mulai dari masa kanakkanak ke masa remaja, dan tanda meningkatnya depresi muncul antara usia 13-15 tahun dan mencapai puncaknya sekitar usia 17-18 tahun dan kemudian menjadi stabil pada usia dewasa. ${ }^{11}$

\section{METODE PENELITIAN}

Penelitian ini merupakan survei deskriptif cross-sectional. Populasi dan sampel diambil sebanyak 30 responden. Teknik pengambilan sampel bertujuan, yaitu memilih sampel dengan kriteria tertentu: berprofesi sebagai Wanita Pekerja Seks; remaja berusia 12-21 tahun; mampu berkomunikasi dengan baik; dan bersedia menjadi responden.

Penelitian ini dilakukan di 3 lokasi kafe di kota Manado, yaitu di kafe Corner (kawasan Bahu Mall), kafe Koulun (Malalayang), dan kafe Hollywood (Tikala Ares). Pengumpulan data dilakukan dengan menggunakan kuesioner data sosiodemografik dan Beck Depression Inventory II. Data sosiodemografik terdiri dari nama samaran; umur; asal daerah/suku; alamat; agama; tingkat pendidikan; lama kerja; dan pendapatan per bulan.

Kuesioner BDI II terdiri dari 21 kelompok pernyataan yang menggambarkan 21 kategori sikap dan gejala depresi untuk membantu mengungkapkan tingkat depresi seseorang. Skor 0 diberikan pada pernyataan yang tidak menggambarkan gejala depresi hingga skor 3 untuk yang menggambarkan gejala depresi yang berat. $^{1}$

Tabel 1. Skor Tingkatan Depresi BDI ${ }^{12}$

\begin{tabular}{cl}
\hline Nilai & Tingkat depresi \\
\hline $0-9$ & Depresi minimal \\
\hline
\end{tabular}


Wardoyo, Kaunang, Munayang; Gambaran Tingkat Depresi pada Wanita Pekerja Seks...

\begin{tabular}{cc}
\hline $10-16$ & Depresi ringan \\
$17-29$ & Depresi sedang \\
$30-63$ & Depresi berat \\
\hline
\end{tabular}

Mengenai definisi operasional dan skala pengukuran ialah sebagai berikut:

1. Jenis WPS ialah penggolongan jenis WPS menurut lokasinya bekerja, yaitu pekerja seks langsung yakni penggolongan bagi para pekerja seks yang mengakui profesinya secara terangterangan dan bisa langsung bertransaksi secara langsung dengan pelanggannya, sedangkan pekerja tidak langsung ialahpara pekerja seks yang tidak mengakui profesinya secara terangterangan dan bertransaksi secara tidak langsung dengan pelanggannya.

2. Usia ialah masa sejak lahir sampai dengan ulang tahun yang terakhir. Dalam hal ini, peneliti mengambil batasan usia remaja 12-21 tahun dengan penggolongan usia remaja awal 12-15 tahun, remaja madya 16-18 tahun dan remaja akhir 19-21 tahun.

3. Suku ialah suatu golongan manusia yang anggota-anggotanya mengidentifikasikan dirinya dengan sesamanya.

4. Agama ialah sistem yang mengatur tata kepercayaan dan peribadatan kepada

Tuhan Yang Maha Kuasa serta tata kaidah yang berhubungan dengan pergaulan manusia dan manusia serta lingkungannya.

5. Tingkat pendidikan ialah tingkat pendidikan terakhir yang diselesaikan responden, terdiri atas tidak sekolah, SD/MA, SLTP, SLTA/SMK, dan Perguruan Tinggi.

6. Lama kerja ialah lamanya subjek bekerja sebagai seorang Wanita Pekerja Seks.

7. Pendapatan per bulan ialah banyaknya pendapatan responden setiap bulan.

Untuk perhitungan frekuensi seluruh variabel yang diteliti menggunakan rumus :

Presentase : $\frac{\boldsymbol{F}}{\boldsymbol{N}} \mathrm{X} 100 \%$

dimana $\mathrm{F}=$ Frekuensi

$$
\mathrm{N}=\text { Jumlah Sampel }
$$

\section{HASIL PENELITIAN}

Dari total sampel 30 responden remaja yang berprofesi sebagai WPS di kota Manado, ditemukan responden yang berprofesi sebagai WPS Tidak Langsung sebanyak $60 \%$ dan WPS Langsung sebanyak 40\%. Jumlah responden terbanyak berada pada rentang usia remaja akhir (1921 tahun) mencakup 73.3\%. Sebagian besar responden yang berpartisipasi berasal dari suku Minahasa (83.3\%) dan sebanyak 90\% responden beragama Kristen Protestan (Tabel 2).

Tabel 2. Distribusi karakteristik remaja WPS di kota Manado berdasarkan jenis WPS, usia, suku, agama, tingkat pendidikan, lama kerja dan pendapatan per bulan.

\begin{tabular}{ccc}
\hline Karakteristik & $\begin{array}{c}\text { Jumlah } \\
\text { Responden }\end{array}$ & \% \\
\hline Jenis WPS & & \\
\hline Langsung & 12 & 40.0 \\
Tidak Langsung & 18 & 60.0 \\
\hline Usia & & \\
\hline Remaja Awal & 0 & 0.0 \\
Remaja Madya & 8 & 26.7 \\
Remaja Akhir & 22 & 73.3 \\
\hline Suku & & \\
\hline Minahasa & 25 & 83.3 \\
Gorontalo & 1 & 3.3 \\
Sangihe & 1 & 3.3 \\
Jawa & 1 & 3.3 \\
Campuran dan & 2 & 6.7 \\
lainnya & & \\
\hline Tingkat Pendidikan & & 0.0 \\
\hline Tidak Sekolah & 0 & 0.0 \\
SD/MA & 0 & 10.0 \\
SLTP & 3 & 83.3 \\
SLTA/SMK & 25 & 6.7 \\
Perguruan Tinggi & 2 & \\
\hline Lama Kerja & & 46.7 \\
\hline <1 tahun & 14 & 53.3 \\
1-3 tahun & 16 & 20.0 \\
>3 tahun & 0 & \\
\hline Pendapatan per Bulan & & \\
\hline > 20 juta & 3 & \\
15-19.9 juta & 7 & 10 \\
10-14.9 juta & 6 & \\
5-9.9 juta & & \\
& & \\
\hline
\end{tabular}


$<5$ juta

4

13.4

Jumlah responden terbanyak berpendidikan terakhir di tingkat SLTA/SMK (83.3\%) dan sebanyak 53.3\% responden bekerja sebagai WPS selama 1-3 tahun. Sebanyak $46.7 \%$ bekerja sebagai WPS kurang dari 1 tahun, dengan rata-rata pendapatan berkisar antara 10-14.9 juta per bulannya (Tabel 2).

Selanjutnya peneliti akan mengklasifikasikan tingkatan depresi menjadi depresi minimal, depresi ringan, depresi sedang dan depresi berat, berdasarkan gejala-gejala depresi yang dirasakan oleh para WPS remaja. Berikut adalah hasil penelitian tentang distribusi frekuensi tingkat depresi WPS remaja di Manado.

Tabel 3. Distribusi Frekuensi Tingkat Depresi WPS Remaja di Manado

\begin{tabular}{ccc}
\hline $\begin{array}{c}\text { Tingkat } \\
\text { Depresi }\end{array}$ & Frekuensi & $\mathbf{\%}$ \\
\hline Minimal & 3 & 10.0 \\
Ringan & 9 & 30.0 \\
Sedang & 11 & 36.7 \\
Berat & 7 & 23.3 \\
\hline
\end{tabular}

Jumlah WPS remaja terbanyak berada pada tingkatan depresi sedang, yaitu sebanyak 11 orang (36.7\%). Sebanyak 9 orang (30.0\%) berada pada tingkat depresi ringan. Jumlah WPS remaja yang berada pada tingkat depresi berat sebanyak 7 orang (23.3\%) dan sebanyak 3 orang (10.0\%) berada pada tingkat depresi minimal atau kondisi normal.

Hasil tingkatan depresi tersebut diperoleh berdasarkan variabel penelitian yang menggambarkan gejala depresi sesuai dengan alat ukur yang digunakan. Variabelvariabel penelitian yang menggambarkan gejala depresi meliputi kesedihan, pesimis, kegagalan masa lalu, kehilangan kenikmatan, perasaan bersalah, perasaan dihukum, ketidaksukaan terhadap diri, kritis diri, pikiran bunuh diri, menangis, gelisah, kehilangan ketertarikan, keraguan, tidak berharga, kehilangan energi, perubahan pola tidur, iritabilitas, perubahan nafsu makan, penurunan berat badan, kelelahan dan kehilangan ketertarikan terhadap seks. ${ }^{13}$ Penjelasan lebih rinci mengenai distribusi frekuensi gejala depresi dapat dilihat pada Tabel berikut ini.

Tabel 4. Distribusi frekuensi gejala depresi wanita pekerja seks (WPS) remaja di Manado

\begin{tabular}{|c|c|c|c|c|}
\hline \multirow{2}{*}{$\begin{array}{l}\text { GEJALA } \\
\text { DEPRESI }\end{array}$} & \multicolumn{4}{|c|}{ PRESENTASE (\%) } \\
\hline & 0 & 1 & 2 & 3 \\
\hline Kesedihan & 50.0 & 30.0 & 10.0 & 10.0 \\
\hline Pesimis & 56.6 & 26.7 & 10.0 & 6.7 \\
\hline Kegagalan & 40.0 & 26.7 & 33.3 & 0.0 \\
\hline $\begin{array}{l}\text { Kehilangan } \\
\text { Kenikmatan }\end{array}$ & 26.7 & 40.0 & 10.0 & 23.3 \\
\hline $\begin{array}{l}\text { Perasaan } \\
\text { Bersalah }\end{array}$ & 13.3 & 50.0 & 26.7 & 10.0 \\
\hline $\begin{array}{l}\text { Perasaan } \\
\text { Dihukum }\end{array}$ & 33.3 & 50.0 & 6.7 & 10.0 \\
\hline $\begin{array}{l}\text { Ketidaksukaan } \\
\text { Terhadap Diri }\end{array}$ & 40.0 & 46.7 & 3.3 & 10.0 \\
\hline Kritis Diri & 43.3 & 13.3 & 10.0 & 33.3 \\
\hline $\begin{array}{l}\text { Pikiran Bunuh } \\
\text { Diri }\end{array}$ & 73.3 & 26.7 & 0.0 & 0.0 \\
\hline Menangis & 20.0 & 30.0 & 3.3 & 46.7 \\
\hline Gelisah & 23.3 & 56.7 & 0.0 & 20.0 \\
\hline $\begin{array}{l}\text { Kehilangan } \\
\text { Ketertarikan }\end{array}$ & 63.3 & 23.3 & 3.3 & 10.0 \\
\hline Keraguan & 33.3 & 26.7 & 33.3 & 6.7 \\
\hline Tidak Berharga & 40.0 & 13.3 & 40.0 & 6.7 \\
\hline $\begin{array}{l}\text { Kehilangan } \\
\text { Energi }\end{array}$ & 40.0 & 33.3 & 26.7 & 0.0 \\
\hline $\begin{array}{l}\text { Perubahan } \\
\text { Pola Tidur }\end{array}$ & 36.6 & 26.7 & 30.0 & 6.7 \\
\hline Iritabilitas & 20.0 & 53.3 & 20.0 & 6.7 \\
\hline $\begin{array}{l}\text { Perubahan } \\
\text { Nafsu Makan }\end{array}$ & 40.0 & 33.3 & 20.0 & 6.7 \\
\hline $\begin{array}{l}\text { Sulit } \\
\text { Konsentrasi }\end{array}$ & 50.0 & 43.3 & 6.7 & 0.0 \\
\hline Kelelahan & 33.3 & 56.7 & 6.7 & 3.3 \\
\hline Minat Sex & 20.0 & 60.0 & 13.3 & 6.7 \\
\hline
\end{tabular}

\section{BAHASAN}

Para remaja yang bekerja sebagai WPS di kota Manado rata-rata berada pada rentang usia 17-21 tahun, dimana jumlah responden terbanyak berada pada usia 19-21 tahun. Menurut Sarwono, umur 19-21 tahun ini berada pada fase remaja akhir, dimana seorang remaja sudah terbentuk identitas seksual secara matang, egosentrisme diganti 
dengan keseimbangan antara diri sendiri dengan orang lain dan mulai timbul dinding antara diri sendiri dan orang lain.

Responden yang berpartisipasi kebanyakan berasal dari suku Minahasa yang merupakan mayoritas suku di kota Manado. Sementara itu hampir seluruh responden beragama Kristen Protestan karena mayoritas suku Minahasa beragama Kristen Protestan.

Pada penelitian ini juga, didapatkan sebagian besar responden telah menyelesaikan program belajar di tingkat SMA/SMK, artinya sudah melalui program wajib belajar sehingga tingkat pendidikan pada WPS dapat dikatakan cukup memadai.

Lama kerja untuk setiap WPS remaja di kota Manado rata-rata berkisar antara 1 hingga 3 tahun dan rata-rata pendapatan per bulan terbanyak berkisar antara 10-14.9 juta rupiah. Angka tersebut tergolong wajar jika dihitung dari banyaknya pelanggan WPS di kota Manado yang mencapai 40 ribu jiwa. Ditambah lagi dengan harga per transaksi yang dipatok dengan harga cukup tinggi yakni berkisar antara 500 ribu hingga 2 juta rupiah. $^{9}$

\section{Prevalensi tingkat depresi WPS remaja di kota Manado}

Berdasarkan hasil data yang diperoleh dari penelitian yang dilakukan di kota Manado, didapatkan sebanyak 76.7\% remaja yang berprofesi sebagai WPS mengalami gangguan depresi, dengan rata-rata berdasarkan skor tingkat depresi sebesar 20.633 atau dapat dibulatkan menjadi 21 (tingkatan sedang). Rata-rata tersebut selaras jika dilihat dari jumlah responden terbanyak yang berada pada tingkatan depresi ringan sebanyak 10 WPS (33.3\%), diikuti responden dengan tingkatan depresi berat sebanyak 8 WPS (26.7\%). Kemudian responden dengan tingkatan depresi minimal atau kondisi normal sebanyak 7 WPS (23.3\%) dan depresi sedang sebanyak 5 WPS (16.7\%).

\section{Gejala depresi WPS remaja di Kota Manado menurut Beck}

Gejala kognitif yang dapat mengidentifikasikan depresi ialah sebanyak 50.0\% WPS cukup sering merasa bersalah, $50.0 \%$ merasa bahwa mereka mungkin dihukum, 46.7\% merasa kecewa terhadap diri mereka sendiri dan $40 \%$ merasa lebih tidak berharga dibandingkan dengan orang lain.

Perasaan bersalah, merasa dihukum, kekecewaan terhadap diri sendiri maupun perasaan tidak berharga merupakan penyebab kognitif yang mengidentifikasikan adanya depresi, karena ketiga hal tersebut merupakan interpretasi negatif tentang diri yang akan berlanjut menjadi depresi yang lebih berat jika tidak mendapatkan penanganan segera. Kondisi tersebut sesuai dengan teori depresi Beck yang menyatakan penyebab kognitif depresi berasal dari interpretasi negatif tentang diri sendiri seperti perasaan bersalah, kekecewaan terhadap diri sendiri, perasaan tidak berharga maupun interpretasi negatif tentang pengalaman hidup seperti perasaan sedang dihukum. ${ }^{14}$

Gejala afektif yang dapat mengidentifikasikan depresi ialah sebanyak 40.0\% WPS tidak dapat menikmati segala sesuatu seperti biasanya, $46.7 \%$ merasa tidak dapat menangis meskipun mereka ingin menangis, $56.7 \%$ merasa lebih gelisah atau tegang daripada biasanya dan 53.3\% merasa lebih mudah jengkel atau marah daripada biasanya.

Gejala-gejala di atas merupakan suatu reaksi afektif atas gejala-gejala kognitif yang WPS rasakan akibat interpretasi diri yang negatif maupun pengalaman hidup yang tidak menyenangkan. Selaras dengan teori hopelessness dimana munculnya depresi berawal dari adanya peristiwa yang menyakitkan yang selanjutnya akan memunculkan perasaan tidak ada harapan dan tidak ada respon yang memungkinkan untuk mengatasi situasi. $^{15}$

Gejala somatik yang dapat mengidentifikasikan depresi ialah sebanyak $63.4 \%$ memiliki gangguan pola tidur, $43.3 \%$ WPS tidak dapat berkonsentrasi dengan baik seperti biasanya, 33.3\% tidak memiliki nafsu makan seperti biasanya, 56.7\% merasa lebih mudah lelah daripada biasanya dan 
60.0\% kurang berminat terhadap seks kalau dibandingkan dengan biasanya.

Menurut Semiun, gejala somatik meliputi gangguan pola tidur, gangguan selera makan dan seks. Dimana gejala-gejala tersebut disebabkan oleh dua faktor, yaitu penyebab yang muncul karena individu mengalami kesedihan dan kesedihan memiliki pengaruh yang mengacaukan; faktor kedua, depresi dikaitkannya dengan bermacam-macam perubahan biokimia dalam otak dan perubahan-perubahan tersebut memengaruhi fungsi hipotalamus, yang pada gilirannya akan memengaruhi pola tidur, selera makan dan seks. ${ }^{16}$

Beberapa gejala somatik lainnya seperti lebih mudah lelah daripada biasanya dan tidak dapat berkonsentrasi dengan baik tidak disebabkan oleh depresi itu sendiri, melainkan hanya merupakan gejala depresi sekunder yang terjadi karena individu tidak tidur dengan baik dan tidak makan dengan baik. ${ }^{16}$

\section{PENUTUP}

Berdasarkan hasil penelitian yang telah dilakukan, didapatkan sebagian besar remaja yang berprofesi sebagai WPS berada pada tahap perkembangan remaja akhir yakni pada rentang usia antara 19-21 tahun sebanyak 73.3\%, suku responden terbanyak yaitu berasal dari suku Minahasa sebanyak 83.3\%, agama responden terbanyak yaitu agama Kristen sebanyak 90.0\%. tingkat pendidikan terakhir responden terbanyak yaitu tingkat SLTA/SMK sebanyak 83.3\%, lama pekerjaan responden terbanyak yaitu selama 1-3 tahun sebanyak 53.3\% dan tingkat pendapatan per bulan responden terbanyak yaitu dengan pendapatan berkisar antara 10-14.9 juta/bulan sebanyak 33.3\%.

Tingkat depresi responden terbanyak adalah tingkat depresi sedang sebanyak $36.7 \%$ dan yang paling sedikit adalah tingkat depresi minimal atau kondisi normal sebanyak $10.0 \%$. Gambaran gejala yang dapat mengidentifikasikan depresi menurut BDI yaitu sebanyak 50.0\% WPS cukup sering merasa bersalah, $50.0 \%$ merasa bahwa mereka mungkin dihukumdan $46.7 \%$ merasa kecewa terhadap diri mereka sendiri. Sebanyak 40\% merasa lebih tidak berharga dibandingkan dengan orang lain, sebanyak 40.0\% WPS tidak dapat menikmati segala sesuatu seperti biasanya, $46.7 \%$ merasa tidak dapat menangis meskipun mereka ingin menangis, 56.7\% merasa lebih gelisah atau tegang daripada biasanya, 53.3\% merasa lebih mudah jengkel atau marah daripada biasanya, $63.4 \%$ memiliki gangguan pola tidur, 43.3\% WPS tidak dapat berkonsentrasi dengan baik seperti biasanya, 33.3\% tidak memiliki nafsu makan seperti biasanya, 56.7\% merasa lebih mudah lelah daripada biasanya dan $60.0 \%$ kurang berminat terhadap seks kalau dibandingkan dengan biasanya.

\section{DAFTAR RUJUKAN}

1. Kaplan HI, Sadock BJ, Grebb JA. Sinopsis Psikiatri: Ilmu pengetahuan perilaku psikiatri klinis. Jilid satu. Editor : Dr. I. Made Wiguna S. Jakarta: Bina Rupa Aksara; 2010. p. 113-29, 149-83.

2. Cilvia N, Widuri EL. Komunikasi ibu dan anak dengan depresi pada remaja. Sumatra Utara : Fakultas Kedokteran USU; 2009.

3. Bjornlund LD. Disease \& Disorders: Depression. United States of America :Gale Cengage Learning; 2010. p. 9-60.

4. Popoola BI. Ocuupational hazards and coping strategies of sex workers in South Western Nigeria. Health Care Women Int. 2013;34:139-49.

5. Harcourt C, Van Beek I, Heslop J, et al. The health and welfare needs of female and transgender street sex workers in New South Wales. Aust N Z J Public Health. 2001;25:84-9.

6. Minichiello V, Marino R, Browne J, et al. Male sex worker in three Australian cities:socio-demographic and sex worker characteristics. JHomosex. 2001;42:29-51.

7. Arnott J. Sex workers and law reform in South Africa. HIV Aids Policy Law rev. 2004;9:78-80

8. Yan Hong Y, Fang $\mathrm{X}, \mathrm{Li} \mathrm{X}$, et al. Selfperceived stigma, depressive symptoms and suicidal behaviours among FSWs in China. J Transcult Nurs. 2010;21:29.

9. Komisi Penanggulangan Aids. Hasil Pemetaan WPS di wilayah Manado. KPA Manado; 2009. 
Wardoyo, Kaunang, Munayang; Gambaran Tingkat Depresi pada Wanita Pekerja Seks...

10. Sarwono SW. Psikologi Remaja. Jakarta: RajaGrafindo Persada; 2006.

11. Marcotte D. Irrational beliefs and depression in adolescence. 2002; 3: 935-48.

12. Beck AT, Steer RA, Brown GK. Manual for the Beck Depression Inventory-II. San Antonio, TX: Psychological Corporation; 1996.

13. Cooper, Erin. Depression among African American female college students: exploratory factor analysis of the Beck Depression Inventory II. ProQuest Dissertations and Theses; 2010.
14. Tarigan CJ. Perbedaan depresi pada pasien dispepsia fungsional dan dispepsia organik. Sumatra Utara: Fakultas Kedokteran USU; 2003.

15. Maulida A. Gambaran tingkat depresi pada mahasiswa program sarjana yang melakukan konseling di badan konseling mahasiswa UI. Depok: Fakultas Ilmu Keperawatan UI; 2012.

16. Semiun Y. Kesehatan mental 2. Yogyakarta: Kanisius; 2006. 